\title{
Dynamics and Socioeconomic Drivers of Illegal Hunting of Wildlife Animal for Consumption in Oba Hills Forest Reserve in Southwest Nigeria
}

\section{${ }^{* 1}$ AKINSOROTAN, OA; ${ }^{2}$ OLANIYI, OE; ${ }^{2}$ OGUNTUASE, BG; ${ }^{1}$ RAHEEM, T}

\author{
${ }^{*}$ Department of Fisheries and Wildlife Management, Osun State University, Nigeria \\ ${ }^{2}$ Department of Ecotourism and Wildlife Management, Federal University of Technology, Akure, Nigeria \\ *Corresponding Author Email: oluseun.akinsorotan@uniosun.edu.ng
}

\begin{abstract}
This study investigated the dynamics and socioeconomic drivers of illegal hunting of wildlife animal commonly called bushmeat in Oba Hills Forest Reserve (OHFR) in Southwest Nigeria. Two hundred and thirty-four households in 8 host communities were subjected to direct household survey using a multi-stage sampling technique. The results revealed that mainly young and middle-aged men engaged in group and seasonal bushmeat hunting, mostly during the dry season. Also, the scale of daily illegal bushmeat hunting is high in the protected area. Non-selective hunting has increased over the last five years with traditional means of hunting still prominent during the hunting expedition. Thus, the socioeconomic drivers (age, ethnicity and household size) had a strong relationship with illegal bushmeat hunting, and their odds ratio ranged between 2.11 and 3.73. Failure to provide stakes for the host communities' inhabitants and weak penal system influenced illegal bushmeat hunting in OHFR. We conclude that the aforementioned factors need to be addressed for illegal bushmeat hunting to be tackled effectively. However, in the absence of political and economic stability, controlling illegal bushmeat hunting will remain extremely difficult and the future of wildlife conservation will remain bleak.
\end{abstract}

DOI: $\underline{\text { https://dx.doi.org/10.4314/jasem.v24i2.15 }}$

Copyright: Copyright (C) 2020 Akinsorotan et al. This is an open access article distributed under the Creative Commons Attribution License (CCL), which permits unrestricted use, distribution, and reproduction in any medium, provided the original work is properly cited.

Dates: Received: 16 November 2019; Revised: 11 January 2020; Accepted: 22 February 2020

Keywords: Protected area, bushmeat hunting, conservation, seasonal employment

Bush meat hunting is becoming a major concern and driver of many wildlife population decline at the local and regional level (Wittemyer et al., 2014). Local people in the tropical forest of Africa depends heavily on bushmeat as a cultural, economic and nutritional component of their livelihood (Nasi et al., 2011). However, the extraction of these wild animal species is unsustainable and leads wildlife populations to local extinctions (Bennett, 2011; Wilkie et al., 2011; FAO, 2018). The need for more money (cash economies) increased access to remote and conservation areas for natural resource extraction. Expansion of logging and mechanized transport provides easy access to most remote parts of the forest (Chaber et al., 2010; UNEP, 2016). Similarly, the widespread use of guns have transformed traditional hunting behavior and increased dependency on the sale of bushmeat to meet urban demands (UNEP, 2016). In Nigeria, the trade in bushmeat is growing at an alarming rate with an estimated volume of 900, 000 kilogram of bushmeat sold annually (Fa et al., 2006; Eniang et al., 2008; Petrozzi et al., 2018). Large profit margins create incentives for the bushmeat trade across all levels of the commodity and supply chain biased towards larger and rare species, allowing bushmeat to reach national and international markets (Coad et al., 2010; Petrozzi et al., 2018). In the Ivory Coast, for example, the bushmeat trade is valued at 150 million USD (Friant et al., 2015). An estimated five tons of bushmeat are smuggled from Africa to Europe per week (Friant et al., 2015). Worldwide, wildlife is second only to narcotics among black market trades (McMurray, 2008). Illegal hunting is detrimental to the existence of large-bodied mammals as they are the most commonly hunted species. Many species have been extirpated from their natural habitats and those still found have their population declining (Usman and Adefalu, 2010; Jayeola et al., 2012; Henschel et al., 2014). For instance, large and medium-size herbivores and apex predators are restricted to few protected areas with an indication of decline in their number owing to unsustainable extraction through illegal hunting (Henschel et al., 2014, Luiselli et al., 2015). Past study revealed that the population of duikers are severely depleted while rock hyrax (Procavia capensis) were not sighted in Tanzania (Nielsen, 2006). Across the central African region between 2002 -2011, over a $60 \%$ decline in forest elephants was recorded with no sign of a fall in the rate of poaching (Maisels et al., 2013). In addition, ungulates in Ivory Coast suffered a decline of over $60 \%$ over 20 years, with poaching through hunting probably the only plausible explanation for the decline (Fisher and Linsenmair, 2001). In addition, Oba Hills Forest Reserve (OHFR) was listed among sites of significance for primate conservation due to past report on the existence of Nigerian-Cameroon Chimpanzee (Pan troglodytes ellioti). However, recent field survey by Nigeria Conservation Foundation confirms that the species might have been extirpated from the forest reserve. 
However, several factors are responsible for illegal bushmeat hunting in Nigeria. Poverty has become a driver of illegal hunting of animals in the wild if there is demand from wealthier communities (Challender and Macmillian, 2014; Nellemann et al; 2016; Knapp et al., 2017; Eli et al., 2017). Many involved either hunt for luxury, to meet market demands for ivory at both local and international level and for meat either for subsistence or commercial uses (Fa et al., 2005). Since poverty is the major driver of illegal bushmeat hunting, a deep knowledge of what constitutes poverty is required. Previous studies have reported that majority of people living in rural areas are poor and belong to the low-income class that lives below $\$ 1.90$ per day (Chen and Ravallion, 2004; FAO, 2017). Income increases with distance away from the park (Wilfred and MacColl, 2010), villages with low income are found at close proximity to the park and engaged more in bushmeat exploitation. Also, conflicts and sizes of a village are an indirect driver as internally displaced people turn to illegal bushmeat hunting for food and for cash income (Jambiya et al., 2007). In addition, lack of an alternative cheap source of protein in rural communities makes the residents dependent on wild animals for their recommended dietary allowance for protein (Nasi et al., 2008; Rentsch and Damon, 2013; Schulte-HerbruEggen et al., 2017). One of the challenges in conservation is changing people's behaviour. Local people whose livelihood solely depends on farming have been assumed to be pre-occupied with a difficult livelihood that led to their involvement in overexploitation of local resources in order to fulfil immediate needs (Mgawe et al., 2010; Duffy et al., 2016). Therefore, improving behavioural change that reduces rule breaking in conservation requires an understanding of the factors that influence decisions about obeying known rules (Keane et al., 2008; St John et al., 2010). Resolving this multi-faceted motivational and povertydriven threat requires different responses. Although, conservation organisations do not see poverty as their primary business/issue of concern (Roe and Elliot, 2006). They are concerned with the escalating rates of illegal bushmeat hunting and trade (Duffy et al., 2016). Despite the general agreement by researchers that illegal bushmeat hunting could have a catastrophic effect on ecosystems and their services (Robinson and Bennett, 2002; Milner-Gulland and Bennet, 2003; Brashere et al., 2004), little is known of the social, economic and other factors that determine human reliance on the natural resources (Abernethy et al., 2013). Investigating the motivation of individuals or communities to engage in illegal bushmeat hunting is an essential first step towards tackling the rate of this illicit behaviour (Brashere et al., 2011; Duffy et al., 2016). This study aims to investigate local people perception and attitude towards bushmeat hunting and to determine the factors influencing illegal hunting of bushmeat in Oba Hills Forest Reserve, Osun State, Nigeria

\section{MATERIALS AND METHODS}

Study area: The study was conducted in and around Oba Hills Forest Reserve, Nigeria (OHFR) (Figure1). The site covered a land mass of about $52.50 \mathrm{~km}^{2}$ in size and located within the Guinea-Congo forest biome. It is situated between latitudes $7^{\circ} 33^{\prime}$ and $7^{\circ} 5^{\prime} \mathrm{N}$ and longitudes $4^{\circ} 02^{\prime}$ and $4^{\circ} 18^{\prime} \mathrm{E}$. The wet and dry seasons are between April - October and November March respectively. The FR has a perennial source of water and it is managed by the Osun State Government in Nigeria. According to Nigerian Conservation Foundation (2013), it is a home to few large mammals, including bushbuck (Tragelaphus scriptus), blue duiker (Cephalophus monicola), cane rat (Thryonomys gregorianus), chimpanzee (Pan troglodytes ellioti) giant pouched rat (Cricetomys), Patas Monkey (Cercopithecus erythrocebus patas) andred-river hog (Potamochoerus porcus). OHFR is characterized by five (5) hills and its vegetation is categorized as derived savannah with a mix of agricultural plots, Teak plantations, woodland habitats and fragments of degraded riparian forests.

Broadly, the vegetation type consists of core forest formation surrounded by savanna ecosystem. However, the two vegetation types have been highly degraded due to encroachment by farmers (illegal), loggers, charcoal makers and hunters. Over the years, most of the savanna and forest ecosystems have been converted to farmlands, apart from two teak plantations. Some savanna trees exist either on the farms or in the fallow portions (Nigerian Conservation Foundation, 2013). These include Borassus aethiopum, Anogeissus lieocarpus, Lophira lanceolata, Sarcocephalus latifolius, Daniellia oliveri, Khaya senegalensis, Newbouldia laevis and Stereospermum kunthianum. There are various communities (enclaves or migrant settlements) within and around the Reserve. The population of the communities varies from 80 to 80,000 . The major occupation in the communities is farming with significant numbers involved in logging, hunting, charcoal making and petty trading.

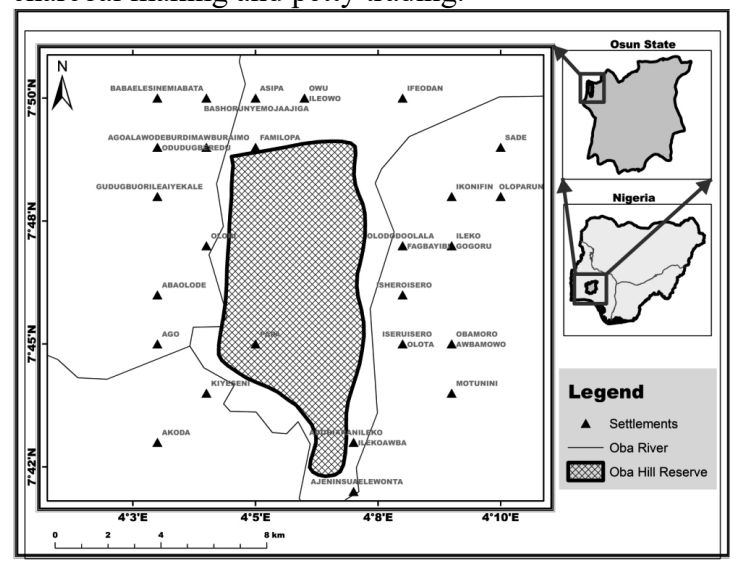

Fig 1: Oba Hills Forest Reserve and its major host communities in the Osun State of Nigeria. 
Data collection: The primary sample unit in this study is the household heads $(\mathrm{HH})$ of the host communities in and around the OHFR. Eight host communities within $5 \mathrm{~km}$ radius to the OHFR boundary were purposively sampled during the 2018 illegal hunting survey. Using cluster sampling, a total of $234 \mathrm{HH}$ were randomly selected from the eight villages - Akinleye (6), Owu-Ile (27), Ife-Odan (104), Isero (9), Ikonifin (53), Olori (21), Familopa (8) and Togunde (6). Due to lack of village register, it was impossible to use a computer-based randomization method or random table to select the HHs. Therefore, a systematic random sampling that entails the selection of every other $\mathrm{HH}$ was employed. HHs interviewed during the survey was from 18 years of age and above. In the absent of the $\mathrm{HH}$ (i.e. if the $\mathrm{HH}$ is a man), the wife or any adult (above 18 years of age) in the family were included in the survey. The questionnaire was completed by the researcher and an assistant in order to avoid non-response to some questions and mistakes by the respondents $(\mathrm{HH})$. Visitation to village heads preceded the interviews to request permission for research activities. After the first visit, each village was visited at least twice and a minimum of 15 minutes was used to survey one person. Oral consent was sought from each $\mathrm{HH}$ prior to the commencement of the survey with options to opt out at any stage of the survey. Primary data were collected using a structured questionnaire (direct questioning) with closed-ended questions in binary and Likert scale formats. These were designed, piloted and administered in the face to face survey of household heads. The household survey was conducted in Yoruba language and an assistance of a bi-lingual indigene that is proficient in speaking Yoruba, Hausa/Fulani language and pidgin (a language spoken as lingua franca across Nigeria) was part of the research team.

Data analysis: The data collected were computer coded and transformed to describe the community's perception of illegal hunting, the preferred methods of hunting and attitude to wildlife conservation. Microsoft Excel and Statistical Package for Social Science (SPSS version 22) were employed in all the statistical analysis. A descriptive analysis was done and the results were presented in percentages and charts. Binary logistic regression was used to determine the local people's socio-demographic factors presumed to influence their participation in the illegal hunting of large mammal. It was performed to identify the predictors of illegal hunting activities and/or behaviour by using the formulae in equation 1 and 2. The independent variables set as dummy variables are age (above 50 years); education (have formal education); ethnicity (nonindiegene/immigrant); income (high income); household size (2-5); occupation (other artisans); attitude (favourable attitude)

\section{RESULTS AND DISCUSSION}

The sample comprised $76.5 \%$ men $(n=179)$ and $23.1 \%$ women $(n=54)$. The age group with the highest frequency was $31-40(42.7 \%)$ followed by $41-50$ years $(34.6 \%), 21-30$ years $(12.4 \%)$ and above 50years $(10.3 \%)$. The majority $(69.7 \%)$ of the respondents were married. Furthermore, a large percentage (68.4\%) was from the Yoruba ethnic group with most respondents comparatively Christians (47.9\%). More than one third $(38.5 \%)$ of the respondents have primary education. Primary occupation is predominantly crop farming $(67 \%)$ without secondary occupation. The majority $(42.3 \%)$ of the respondents reported having an annual income of below N300, 000 (less than $\$ 2$ per day).

Local community's perception of illegal bushmeat hunting in OHFR: More than two-thirds (83.3\%) of the respondents were of the opinion that neighbours enter the reserve to hunt. Also, more than half $(58.1 \%)$ of the respondents reported group hunting as a common practice during hunting expedition. Despite this opinion, $62.4 \%$ of the villagers frequently engaged in individual hunting. The result further indicates that hunting expedition was perceived to be conducted mostly (50.9\%) during the dry season. Combination of Dane gun, snares and capture by gripping were commonly used (59\%) during hunting expedition. One third $(30.8 \%)$ of the villagers perceived that illegal bushmeat hunting occurs in the reserve every day. The majority $(77.8 \%)$ of the respondents reported that some species of animals are no longer found in the reserve (Table 2).

$$
\begin{gathered}
\text { Ln }=\beta_{0}+\beta_{1} A+\beta_{2} E+\beta_{3} E T+\beta_{4} I+\beta_{5} O+\beta_{6} A+\beta_{7} H+\text { Error } \ldots \text { (1) } \\
\operatorname{Pr}(P)=\frac{\exp \left(\beta_{0}+\beta_{1} \mathrm{~A}\right)}{1+\exp \left(\beta_{0}+\beta_{1} \mathrm{~A}\right)} \ldots \ldots \ldots \text { (2) }
\end{gathered}
$$

Where: $\ln =$ the logit function, $\mathrm{Pr}=$ is the probability of The trend of illegal hunting in OHFR: Figures $2 \mathrm{a}, \mathrm{b}$ event, $\mathrm{P}=$ is the response variable (Bushmeat hunting) $\beta_{0}=$ is the intercept, $\beta_{1}, \beta_{2} \ldots \beta_{7}=$ is the regression coefficients, A (age), E (education), ET (Ethnicity), I (Income), O (Occupation), A (Attitude), H (Household size $)=$ set of predictors (independent variables) The trend of illegal hunting in OHFR: Figures $2 \mathrm{a}, \mathrm{b}$
and $\mathrm{c}$ showed that most $(73.5 \%)$ of the respondents reported that illegal hunting practice has been since the inception of OHFR. More than two-thirds (65.8\%) of the villagers affirmed that hunting has increased over the last five years. In addition, $62 \%$ reported the type 
of animal killed during hunting as non-selective i.e. any animal seen is hunted during hunting expenditure.

Attitude towards bushmeat hunting and wildlife conservation: Local people attitude towards hunting and wildlife conservation in OHFR is presented in Table 1. Overall, respondents had an unfavourable attitude towards bushmeat hunting and wildlife conservation. Nevertheless, attitudes differed with specific statements. The statements for which villagers showed positive attitudes were: 'Presence of animal is a sign of a healthy environment' [63.25\% agree; mean $(\mathrm{SD})=3.56$ (1.44)]; 'These days I think killing any species of animals inside the forest reserve is wrong" $[41.45 \%$ agree; mean $(\mathrm{SD})=2.97(1.57)]$.

Local people perception of bushmeat trade and consumption: Table 2 showed the local people perception on bushmeat trade and consumption. The majority $(79.1 \%)$ of the respondents were of the opinion that bushmeat hunting is mostly for consumption, and had been a tradition since the inception $(64.1 \%)$ of the reserve. Food vendors are the major targets $(54.7 \%)$ for the bushmeat trade. Whole meat (carcases) are frequently sold (45.3\%) as regards the animal part usually sold. Both young and middleaged men were indicated as those engaged in bushmeat hunting and trade in OHFR by $26.5 \%$ of the respondents. $50.9 \%$ of the respondents indicated to join the community of hunters/hunters group in the locality.

Factors influencing illegal bushmeat hunting in OHFR: Socioeconomic drivers of illegal bushmeat hunting in OHFR are presented in Table 3. 3 socioeconomic predictors highly influence the illegal bushmeat hunting ( $\mathrm{P} \leq 0.01)$ - Age (31-40years), ethnicity (Yoruba) and household size (Above 9). Also, 3 socioeconomic predictors moderately influence the illegal bushmeat hunting $(\mathrm{P} \leq 0.05)$ - Age (21-30years), Education (do not have a formal education) and Primary occupation (crop farming). However, 5 socioeconomic predictors had no significant influence on the illegal bushmeat hunting Age (41-50years), Primary occupation (livestock farming), low income, Attitude towards wildlife (not favourable), and Household size (6-9). Thus, the age, ethnicity and household size had a strong relationship with illegal bushmeat hunting, and their odds ratio ranged between 2.11 and 3.73. Cox and Snell, and Nagelkerke R squared estimates specify that the whole model explained between $66 \%$ and $93 \%$ of the variance that can be predicted from the socioeconomic predictors.

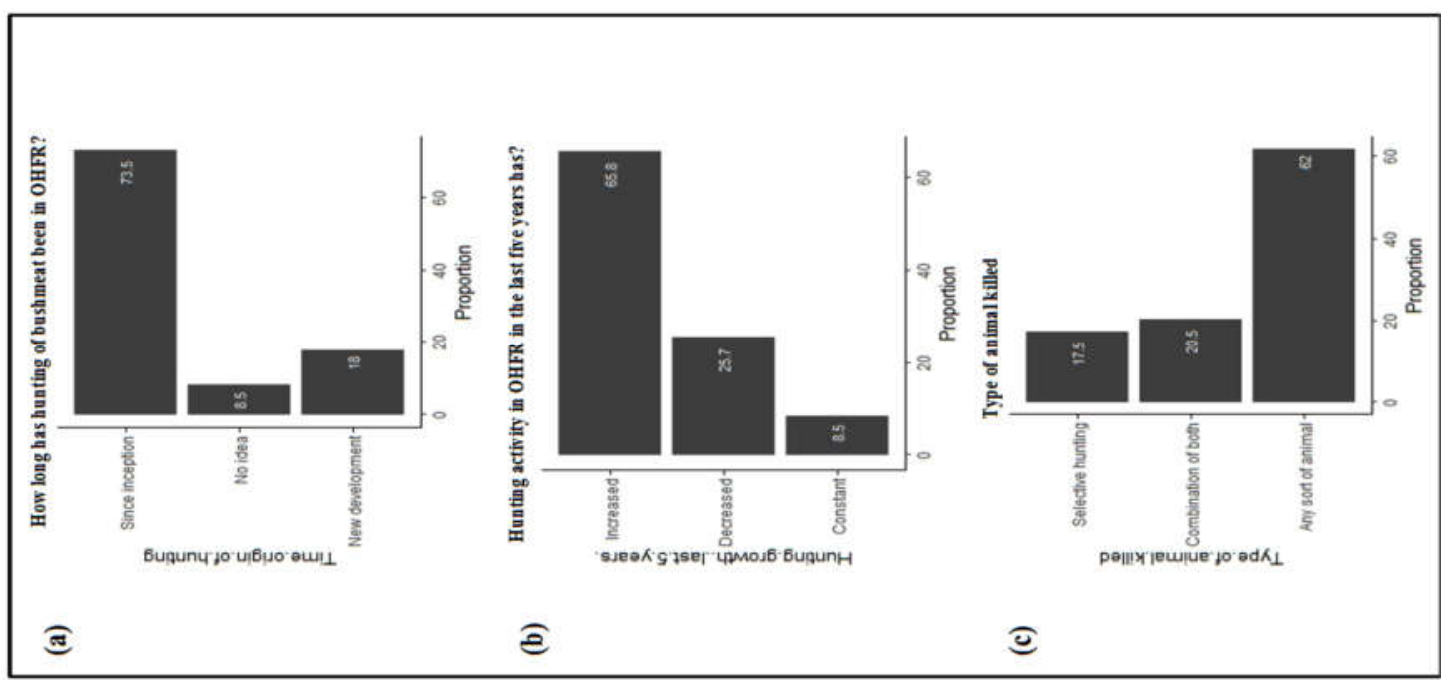

Fig 2: The trend of illegal bushmeat hunting in OHFR 


\begin{tabular}{|c|c|c|c|c|c|c|}
\hline Item & Variable $(\mathrm{N}=\mathbf{2 3 4})$ & Agree & Unsure & Disagree & NO & Mean (SD) \\
\hline 1 & The existence of wildlife will persist forever & $207(88.46)$ & $21(8.97)$ & $6(2.56)$ & - & $1.58(.78)$ \\
\hline 2 & There are so many animals left not hunted in the reserve & $184(78.63)$ & $25(10.68)$ & $24(10.26)$ & $1(.43)$ & $1.88(.98)$ \\
\hline 3 & Hunting is a danger to the continued existence of wildlife & $110(47.01)$ & $58(24.79)$ & $50(21.37)$ & $16(2.56)$ & $3.27(1.45)$ \\
\hline 4 & Wild animal should be protected & $106(45.30)$ & $38(6.24)$ & $70(29.92)$ & $10(4.27)$ & $3.16(1.41)$ \\
\hline 5 & Presence of animal is a sign of a healthy environment & $148(63.25)$ & $35(14.96)$ & $36(15.39)$ & $15(6.4)$ & $3.56(1.44)$ \\
\hline 6 & $\begin{array}{l}\text { I think we should be allowed to kill any species of animals } \\
\text { inside the forest reserve }\end{array}$ & $133(56.84)$ & $20(8.55)$ & $64(27.35)$ & $17(7.26)$ & $2.73(1.22)$ \\
\hline 7 & $\begin{array}{l}\text { I think I should be allowed to kill any species of animal } \\
\text { outside the forest reserve }\end{array}$ & $151(64.53)$ & $16(2.56)$ & $59(25.21)$ & $8(3.42)$ & $2.38(1.62)$ \\
\hline 8 & $\begin{array}{l}\text { I think I should be allowed to trap or kill any wild animal } \\
\text { that are found in the field damaging crops or attacking } \\
\text { livestock }\end{array}$ & $149(63.68)$ & $9(3.85)$ & $71(30.34)$ & $5(2.14)$ & $2.35(1.45)$ \\
\hline 9 & $\begin{array}{l}\text { These days I think killing any species of animals inside the } \\
\text { forest reserve is wrong }\end{array}$ & $97(41.45)$ & $42(17.95)$ & $85(36.32)$ & $10(4.27)$ & $2.97(1.57)$ \\
\hline 10 & $\begin{array}{l}\text { These days I think I should not be allowed to trap or kill any } \\
\text { wild animal that are found in the fields damaging crops or } \\
\text { attacking livestock }\end{array}$ & $78(33.33)$ & $14(5.98)$ & $122(52.14)$ & $20(8.55)$ & $2.49(1.54)$ \\
\hline 11 & $\begin{array}{l}\text { Wildlife protection should involve restrictions against } \\
\text { hunting in the reserve }\end{array}$ & $109(46.58)$ & 21(8.97) & $81(34.62)$ & $23(9.83)$ & $2.41(1.32)$ \\
\hline
\end{tabular}

Table 2: Local people perception of bushmeat hunting and trade in OHFR

\begin{tabular}{lll}
\hline Variables (N=234) & Frequency & Percentage \\
\hline Is bushmeat hunting for consumption? & & \\
Yes & 185 & 79.1 \\
No & 49 & 20.9 \\
If yes, How long have this bushmeat trade been? & & \\
Since inception of the reserve & 150 & 64.1 \\
A new development & 48 & 20.5 \\
A decade ago or more & 36 & 15.4
\end{tabular}

$\begin{array}{lcc}\text { Does the bushmeat trade involve selective trade of animal parts or whole meat sales? } \\ \text { Selective trade in animals parts } & 57 & 24.4 \\ \text { Whole meat sales } & 106 & 45.3 \\ \text { Combination of both } & 71 & 30.3 \\ \text { What are the major targets for bushmeat trade? } & 128 & 54.7 \\ \text { Food vendors } & 29 & 12.4 \\ \text { Herb practitioners } & 66 & 28.2 \\ \text { Both } & 11 & 4.7 \\ \text { Others } & 119 & 50.9 \\ \text { Would you like to join the community of hunters in your locality? } & \\ \text { Yes } & 115 & 49.1 \\ \text { No } & 41 & 17.5 \\ \text { Who are the people involved in bushmeat hunting and trade in the community? } & 13.7 \\ \text { Young } & 32 & 17.5 \\ \text { Middle aged } & 41 & 24.8 \\ \text { Aged } & 58 & 26.5 \\ \text { Combination of all } & 62 & \\ \text { Young and middle aged } & \end{array}$

$N=$ sample size

The surveys conducted in the villages neighbouring OHFR revealed that over $77.6 \%$ of household heads resident in study area are men of working age that can engage in any economic activity. In accordance with past studies adult male are presume to have inclination and opportunity to hunt (Kumpel et al., 2010; Lindsey et al., 2013). Personal characteristics of illegal hunters are local, financially poor, food - insecure young men (Lindsey et al., 2011). In south-eastern Zimbabwe, most men between the ages of 21 to 50 years were reported to be involved in illegal hunting (Gandiwa et al., 2014). Most of them are classed as poor, as the majority fall into the low-income group. Poor people in remote, marginal or forested areas are believed to have limited livelihood opportunities and so depend on the natural resources for food and other essentials (Roe and Elliot, 2006; Eli et al., 2017). The livelihood strategies of local residents in this study mirror those obtained in past studies as respondents are mostly crop farmers with no secondary occupation nor educational level (Abernethy et al., 2013; Duffy et al., 2016). For example, the majority of rural people in eastern Madagascar were found to be farmers (Jenkins et al., 2011). It is interesting to note that those whose occupation is farming are probably involved in hunting (hunter - farmer), by investing the income from agriculture in increased bushmeat consumption and newer hunting equipment (Duffy et al., 2016). This characteristic made the villagers vulnerable and increased their chances of being involved in illegal activities (Gandiwa, 2011) inside the park since there is a need for them to meet resource demand for their 
household. Further analyses of the data will be undertaken to examine if this is indeed the case.

The survey indicates that the community had some level of involvement in illegal hunting. A large proportion $(83.3 \%)$ of the respondents agreed that people entered the park to hunt animals. One possible explanation for the reason why a larger number of informants agreed to neighbours illicit behaviour could be the indirect way of asking a sensitive question, as people may prefer to report neighbours undesirable behaviour. The result of this present study corroborates with the assertion from past authors that indirect questioning in survey evokes higher responses of socially undesirable behaviour. Moreover, group hunting as the common practice and the use of a gun during hunting expedition is detrimental to the population of wild animals in the study. This indiscriminate and unsustainable method of extracting wild animals could have resulted in the disappearance of some species of animals as reported by the respondents.

Table 3: Socioeconomic drivers of illegal bushmeat hunting in OHFR

\begin{tabular}{|c|c|c|c|c|}
\hline Independent variables & $\mathbf{B}$ & $\begin{array}{l}\text { Standard } \\
\text { error }\end{array}$ & Sig. & $\operatorname{Exp}(B)$ odds \\
\hline \multicolumn{5}{|l|}{ Age (Above 50years as reference category) } \\
\hline Age (21-30years) & 1.43 & 0.69 & $0.05 *$ & 1.54 \\
\hline Age (31-40years) & 1.01 & 0.59 & $0.03 * *$ & 3.73 \\
\hline Age (41-50years) & 0.99 & 0.59 & 0.10 & 2.68 \\
\hline \multicolumn{5}{|l|}{ Ethnicity (immigrant as reference category) } \\
\hline $\begin{array}{l}\text { Ethnicity (Yoruba) } \\
\text { Education (have formal education as reference category) }\end{array}$ & 1.29 & 0.37 & $0.02 * *$ & 1.75 \\
\hline \multicolumn{5}{|l|}{ Primary occupation (other artisans as reference category) } \\
\hline Primary occupation (crop farming) & 2.38 & .37 & $0.04 *$ & 1.33 \\
\hline \multicolumn{5}{|l|}{ Income (high income as reference category) } \\
\hline $\begin{array}{l}\text { Income (low) } \\
\text { Attitude (favorable attitude as reference category) }\end{array}$ & $\begin{array}{ll}0 & .51\end{array}$ & 0.31 & 0.10 & 0.60 \\
\hline $\begin{array}{l}\text { Attitude towards wildlife (not favorable) } \\
\text { Household size (household size } 2-5 \text { as reference category) }\end{array}$ & 0.50 & 0.33 & 0.13 & 1.65 \\
\hline Household size (6-9) & 0.50 & 0.40 & 0.27 & 1.55 \\
\hline Household size (Above 9) & 3.12 & 1.21 & $0.00 * *$ & 2.11 \\
\hline Model $\chi^{2}$ & 853.01 & & & \\
\hline
\end{tabular}

The rather high level of awareness of hunting season can partially be linked to community involvement in the illegal hunting activity. The findings in this study mirror those of previous studies where about $50 \%$ of the informants admitted illegal hunting activities and the existence of hunting seasons in their communities (Gandiwa, 2011; Bitanyi et al., 2012; Nachihangu et al., 2018) that have examined wildlife resource use. Therefore, it is reasonable to assume that the scale of illegal hunting of wild animals is still considerable in this forest reserve. However, wild animals in their natural home are severely depleted and at risk of extirpation from illegal hunting for both subsistence and commercial purposes (Ripple et al., 2016; BenitezLopez et al., 2017). The findings from this study indicate that hunting practices have been from the inception of the reserve and the trend has increased with all sort of animals targeted and killed resulting in large mammal species population depletion. This general perceived decline in large mammal abundance supports the higher proportion of the local people reporting the reduction in the number of animal species seen in this study. Although respondents were not asked for lists the species not seen over the years that were once present. A possible explanation for this result may be that large mammal species with either low or high population trends have been negatively affected by illegal hunting. As a result of the depleted status of wildlife population, there is an indication that bushmeat will contribute little to hunters' livelihood in a long-term food security option. People in the neighbouring community to the reserve had negative attitudes towards hunting/wildlife. This figure is high, despite the expected restrictions on natural resource use in the reserve. Unsustainable exploitation of natural resources through the displacement of people from their traditional lands (Muhumuza and Balkwill, 2013; Olaniyi et al., 2019) could explain this negative attitude and non-acceptance of conservation policy. The age was observed to be as one of the factors that significantly associate with illegal hunting in OHFR. The likelihood of an individual engaging in hunting of wild animals increases with ages under 30 years and between 31-40 years respectively. This present result further established past findings that identified age as an important factor influencing those that engaged in illegal hunting in other African countries (Loibooki et al., 2002; Gandiwa et al., 2014). For example, in southeastern Zimbabwe, most men between the ages of 21 to 50 years were reported to be involved in illegal hunting (Gandiwa et al., 2014). Similarly, most men involved in bushmeat hunting in Botswana are young adults (Lindsey, 2016). Therefore people who tend to hunt bushmeat in OHFR are young adult males of between 21 years of age to 40 years. This will probably have a negative influence on the biodiversity in the 
OHFR as these men can engage in any economic activity to provide food security for their family especially during the dry season.

Various studies have found that ethnicity can significantly increase the rate of illegal hunting among the residents of protected areas (de Merode and Cowlishaw, 2006; Jambiya et al., 2007; Duffy et al., 2016). In accordance with past research, our findings showed that the indigenous residents (Yoruba's) are more likely to hunt wild animals than the immigrants. A similar study in Tanzania revealed that indigenous populations use their traditional sources of wealth and means to obtain bushmeat for consumption (Mgawe et al., 2012). The findings of the current study corroborate with the ideas of Naughton-NaughtonTreves, (2002) and Shenck et al., (2006) who suggested that people whose rural tradition and /or religion do not include bushmeat consumption are less likely to it eat because individuals often express negative feelings towards unfamiliar food. However, limitations on natural resource use may be seen as a denial of traditional rights especially among indigenous people that are culturally inclined to bushmeat consumption. The effect can cause a negative attitude towards conservation (Arjunan et al., 2006; Tomicevic et al., 2010). Therefore, the ethnicity of the residents in this study appeared not to favour sustainable hunting of wild animals. However, an effective strategy that provides indigenous people with a strong attachment to wildlife should be educated, encouraged, trained and supported in the domestication of some of the wild animal species preferred by the group. Also, the current study found a significant influence of education on the likelihood of individuals who had no formal education belongs to be engaged in bushmeat hunting. Most individuals are not educated and those educated only completed the primary education which may prevent them to earn a higher and stable income.

A higher education enabled better and stable paid job while a low and/or no formal education will have less opportunity to have a stable income and hence depend on the wildlife resources for survival. This further support the findings that educated households have higher income and do not engage in illegal hunting in Tanzania (Wilfred and MacColl, 2010; Moro et al., 2013). Nevertheless, poor rural people are more prone to livelihood hardship and therefore, will engage in any economic activities to get stable income and sustenance (Lindsey et al., 2011, Nielsen and Meilby, 2015). On the contrary, other researchers have found that both poor and wealthier households involved in illegal hunting (Brashares et al., 2011). This conflicting idea depends on what motivates those involved in illegal hunting. Depending on the economic factor, some may hunt for the table while other may hunt for commercial gain (Mancini et al., 2011; Bi et al., 2016).
The respondent's livelihood strategies are majorly crop farming with no alternative source of income during the lean season. Research has demonstrated that farming as an occupation can influence those practising it to engage in bushmeat hunting (Fusari and Carpaneto, 2006; Duffy et al., 2016; Lindsey et al., 2016). It is interesting to note that those whose occupation is farming are probably involved in hunting too (hunter - farmer). They invested the income from agriculture in increased bushmeat consumption and new hunting equipment (Duffy et al., 2016). This characteristic made the villagers vulnerable and increased their chances of being involved in illegal bushmeat hunting (Gandiwa, 2011). About 90\% of household production sold at market in Democratic Republic of Congo is derived from wildlife, compared to $25 \%$ for agricultural production (de Merode et al., 2003). It is evident that the market sale and not consumption of bushmeat is most important to poor households and a major driver of commercial bushmeat hunting. This in turn, is potentially a bigger conservation threat than subsistence hunting (Duffy et al., 2016).

Furthermore, the likelihood of engaging in bushmeat hunting is significantly influenced by the household size (large/increase). This result contradicts past research that found a strong relationship with household size (smaller/decrease) and bushmeat consumption in Gabon, as household size increased, consumption of bushmeat decreased (Foerster et al., 2012). One possible explanation for bushmeat hunting to increase with an increase in household size (above 9) could be attributed to the poverty level of local people neighbouring protected areas that could influence individual into the illicit act in other to provide food for his family. In addition, bushmeat is the cheapest and easily affordable and accessible source of animal protein to local people, hence will flout any laws to sustain and improve their family nutritional level. Other potential drivers and explanation for bushmeat hunting activities and/or behaviour considered in this study are: income and attitude but their effects do not statistically influence the individual's likelihood to be engaged in bushmeat hunting.

Conclusion: Communities in OHFR are involved in illegal hunting not because they lack knowledge of the reasons and importance of conservation of wildlife species. Their involvements were due to unemployment, a lack of alternative livelihood, and sources of animal protein. In addition, the wildlife policy does not promote peoples involvement in wildlife conservation, and the local residents were in no way benefiting from the direct use of wildlife resources. These findings may help us to understand the need for diversifying sources of income and for the adoption of poverty reduction policies that are 
conservation-friendly to help provide sustainable livelihood opportunities in local communities.

\section{REFERENCES}

Abernethy, K.A.; Coad, L.; Taylor, G.; Lee, M.E.; Maisels, F. (2013). Extent and ecological consequences of hunting in Central African rainforests in the twenty-first century [online]. . Available at: http://rstb.royalsocietypublishing.org/content/368 /1625/20120303 [Accessed 01/15 2014].

Arjunan, M.; Holmes, C.; Puyravaud, J.; Davidar, P. (2006). Do developmental initiatives influence local attitudes toward conservation? A case study from the Kalakad-Mundanthurai Tiger Reserve, India. Journal of Environmental Management, 79 (2), 188-197.

Atuo, F.A.; Ivande, S.T.; Wala, Z.; O'Connell, T.J. (2014). Effects of hunting camps on breeding grey-necked picathartes Picathartes oreas in south-east Nigeria. Oryx, 48 (03), 460-464.

Balmford, A.; Cowling, R.M. (2006). Fusion or failure? The future of conservation biology. Conservation Biology, 20 (3), 692-695.

Benítez-López, A.; Alkemade, R.; Schipper, A.M.; Ingram, D.J.; Verweij, P.A.; Eikelboom, J.A.J.; Huijbregts, M.A.J. (2017). The impact of hunting on tropical mammal and bird populations. Science 356: $180-183$.

Bennett, E.L. (2011). Another inconvenient truth: the failure of enforcement systems to save charismatic species. Oryx, 45 (04), 476-479.

Bi, S.G.; Koné, I.; Béné, J.; Bitty, E.; Yao, K.; Kouassi, B.; Gaubert, P. (2016). Bushmeat hunting around a remnant coastal rainforest in Côte d'Ivoire. Oryx, , 1-10.

Bitanyi, S.; Nesje, M.; Kusiluka, L.J.; Chenyambuga, S.W.; Kaltenborn, B.P. (2012). Awareness and perceptions of local people about wildlife hunting in western Serengeti communities. Tropical Conservation Science, 5 (2), 208-224.

Brashares, J.S.; Arcese, P.; Sam, M.K.; Coppolillo, P.B.; Sinclair, A.R.; Balmford, A. (2004). Bushmeat hunting, wildlife declines, and fish supply in West Africa. Science (New York, N.Y.), 306 (5699), 1180-1183.

Brashares, J.S.; Golden, C.D.; Weinbaum, K.Z.; Barrett, C.B.; Okello, G.V. (2011). Economic and geographic drivers of wildlife consumption in rural Africa. Proceedings of the National Academy of Sciences of the United States of America, 108 (34), 13931-13936.
Carpaneto, G.M.; Fusari, A.; Okongo, H. (2007). Subsistence hunting and exploitation of mammals in the Haut-Ogooué province, south-eastern Gabon. Journal of Anthropological Sciences, 85, 183-193.

Chaber, A.; Allebone-Webb, S.; Lignereux, Y.; Cunningham, A.A.; Marcus Rowcliffe, J. (2010). The scale of illegal meat importation from Africa to Europe via Paris. Conservation Letters, 3 (5), 317-321.

Challender, D.W.; MacMillan, D.C. (2014). Poaching is more than an enforcement problem. Conservation Letters, 7 (5), 484-494.

Chen, S.; Ravallion, M. (2004). How have the world's poorest fared since the early 1980s? The World Bank Research Observer, 19 (2), 141-169.

Chivian, E.; Bernstein, A. (2008). Sustaining life: how human health depends on biodiversity. Oxford University Press.

Coad, L.; Abernethy, K.; Balmford, A.; Manica, A.; Airey, L.; Milner-Gulland, E.J. (2010). Distribution and use of income from bushmeat in a rural village, central Gabon. Conservation Biology, 24 (6), 1510-1518.

Corlett, R.T. (2007). The impact of hunting on the mammalian fauna of tropical Asian forests. Biotropica, 39 (3), 292-303.

Costa-Neto, E.M. (2005). Animal-based medicines: biological prospection and the sustainable use of zootherapeutic resources. Anais Da Academia Brasileira De Ciências, 77 (1), 33-43.

De Merode, E.; Cowlishaw, G. (2006). Species protection, the changing informal economy, and the politics of access to the bushmeat trade in the Democratic Republic of Congo. Conservation Biology, 20 (4), 1262-1271.

De Merode, E.; Homewood, K.; Cowlishaw, G. (2003). Wild resources and livelihoods of poor households in Democratic Republic of Congo. ODI Wildlife Policy Briefing, 1 (1), 1-4.

De Merode, E.; Homewood, K.; Cowlishaw, G. (2004). The value of bushmeat and other wild foods to rural households living in extreme poverty in Democratic Republic of Congo. Biological Conservation, 118 (5), 573-581.

Duffy, R.; St John, F.A.; Büscher, B.; Brockington, D. (2016). Toward a new understanding of the links 
between poverty and illegal wildlife hunting. Conservation Biology, 30 (1), 14-22.

Ejiofor, T.; Ali, C.C. (2014). Wildlife Conservation and Management: Hindrances and Sustainable Measures among Local Users in Igbo-Eze North Agricultural Zone, Enugu State, Nigeria. Journal of Agriculture and Biodiversity Research, 3 (5), 61-67.

Eniang, E.A.; Eniang, M.E.; Akpan, C.E. (2008). Bush meat trading in the Oban Hills region of southeastern Nigeria: implications for sustainable livelihoods and conservation. Ethiopian Journal of Environmental Studies and Management, 1 (1), 70-83.

Enuoh, O.O.; Bisong, F.E. (2014). Rural Livelihoods Vulnerabilities and Commercial Bushmeat Hunting Challenges in Cross River National Park, Nigeria. Natural Resources, 5 (13), 822.

Fa, J.E.; Juste, J.; Burn, R.W.; Broad, G. (2002). Bushmeat consumption and preferences of two ethnic groups in Bioko Island, West Africa. Human Ecology, 30 (3), 397-416.

Fa, J.E.; Ryan, S.F.; Bell, D.J. (2005). Hunting vulnerability, ecological characteristics and harvest rates of bushmeat species in afrotropical forests. Biological Conservation, 121 (2), 167176.

Fa, J.E.; Seymour, S.; Dupain, J.; Amin, R.; Albrechtsen, L.; Macdonald, D. (2006). Getting to grips with the magnitude of exploitation: bushmeat in the Cross-Sanaga rivers region, Nigeria and Cameroon. Biological Conservation, 129 (4), 497-510.

FAO (2017). The future of food and agriculture Trends and challenges. Rome. Pp180

FAO (2018). Developments in the field of sustainable wildlife management in Africa. African Forestry and Wildlife Commission. 21st Session, Dakar, Senegal, 19 - 23 June 2018. FO: AFWC/2018/10. Pp5

Fischer, F.; Linsenmair, K.E. (2001). Decreases in ungulate population densities. Examples from the Comoé National Park, Ivory Coast. Biological Conservation, 101 (2), 131-135.

Friant, S.; Paige, S. B.; Goldberg, T. L. (2015). Drivers of bushmeat hunting and perceptions of zoonoses in Nigerian hunting communities. PLoS neglected tropical diseases, 9(5), e0003792.
Fusari, A.; Carpaneto, G.M. (2006). Subsistence hunting and conservation issues in the game reserve of Gile, Mozambique. Biodiversity \& Conservation, 15 (8), 2477-2495.

Gandiwa, E. (2011). Preliminary assessment of illegal hunting by communities adjacent to the northern Gonarezhou National Park, Zimbabwe. Tropical Conservation Science, 4 (4), 445-467.

Gandiwa, E.; Zisadza-Gandiwa, P.; Mango, L.; Jakarasi, J. (2014). Law enforcement staff perceptions of illegal hunting and wildlife conservation in Gonarezhou National Park, southeastern Zimbabwe. NuSpace Institutional Repository, 55 (1), 119-127.

Harrison, M.; Roe, D.; Baker, J.; Mwedde, G.; Travers, H.; Plumptre, A.; Rwetsiba, A.; Milner-Gulland, E. (2015). Wildlife crime: a review of the evidence on drivers and impacts in Uganda. IIED, London.

Henschel, P.; Coad, L.; Burton, C.; Chataigner, B.; Dunn, A.; MacDonald, D.; Saidu, Y.; Hunter, L.T. (2014). The lion in West Africa is critically endangered. PloS One, 9 (1), e83500.

Jambiya, G.; Milledge, S.; Mtango, N. (2007). Night time spinach. Dar es Salaam (Tanzania) TRAFFIC East/Southern Africa. Available at: http://www.traffic.org/generalreports/traffic_pub_gen16.pdf [Accessed 10/19 2015].

Jayeola, O.; Onadeko, S.; Mafiana, C.; Inah, E.; Okeyoyin, O. (2012). Past and present status of kob (Kobus (Adenota) kob (Erxleben) in Nigeria. International Journal of Biodiversity and Conservation, 4 (5), 197-205.

Jenkins, R.K.; Keane, A.; Rakotoarivelo, A.R.; Rakotomboavonjy, V.; Randrianandrianina, F.H.; Razafimanahaka, H.J.; Ralaiarimalala, S.R.; Jones, J.P. (2011). Analysis of patterns of bushmeat consumption reveals extensive exploitation of protected species in eastern Madagascar. PloS One, 6 (12), e27570.

Keane, A.; Jones, J.P.; Edwards-Jones, G.; MilnerGulland, E.J. (2008). The sleeping policeman: understanding issues of enforcement and compliance in conservation. Animal Conservation, 11 (2), 75-82.

Knapp, E.J.; Peace, N.; Bechtel, L. (2017). Poachers and Poverty: Assessing Objective and Subjective Measures of Poverty among Illegal Hunters Outside Ruaha National Park, Tanzania. Conservation and Society 15(1): 24-32. 
Kühl, A.; Balinova, N.; Bykova, E.; Arylov, Y.N.; Esipov, A.; Lushchekina, A.A.; Milner-Gulland, E. (2009). The role of saiga poaching in rural communities: linkages between attitudes, socioeconomic circumstances and behaviour. Biological Conservation, 142 (7), 1442-1449.

Kümpel, N.F.; Milner-Gulland, E.; Cowlishaw, G.; Rowcliffe, J.M. (2010). Incentives for hunting: the role of bushmeat in the household economy in rural Equatorial Guinea. Human Ecology, 38 (2), 251-264.

Laporte, N.T.; Stabach, J.A.; Grosch, R.; Lin, T.S.; Goetz, S.J. (2007). Expansion of industrial logging in Central Africa. Science (New York, N.Y.), 316 (5830), 1451.

Lindsey, P.; Bento, C. (2012). Illegal hunting and the bushmeat trade in Central Mozambique. a casestudy from Coutada 9, Manica Province [online]. Available at: http://www.gorongosa.org/sites/default/files/rese arch/031-traffic_pub_gen48.pdf [Accessed 10/06 2014].

Lindsey, P. (2010). The future of wildlife-based land uses in Botswana. Animal Conservation, 9, 283298.

Lindsey, P.A.; Balme, G.; Becker, M.; Begg, C.; Bento, C.; Bocchino, C.; Dickman, A.; Diggle, R.W.; Eves, H.; Henschel, P. (2013). The bushmeat trade in African savannas: Impacts, drivers, and possible solutions. Biological Conservation, 160, 80-96.

Lindsey, P.A.; Romanach, S.; Matema, S.; Matema, C.; Mupamhadzi, I.; Muvengwi, J. (2011). Dynamics and underlying causes of illegal bushmeat trade in Zimbabwe. Oryx, 45 (01), 8495.

Litchfield, C. (2013). Telling the truth about animals and environments. Motivating Change: Sustainable Design and Behaviour in the Built Environment, , 153.

Loibooki, M.; Hofer, H.; Campbell, K.L.; East, M.L. (2002). Bushmeat hunting by communities adjacent to the Serengeti National Park, Tanzania: the importance of livestock ownership and alternative sources of protein and income. Environmental Conservation, 29 (03), 391-398.

Luiselli, L.; Amori, G.; Akani, G.C.; Eniang, E.A. (2015). Ecological diversity, community structure and conservation of Niger Delta mammals.
Biodiversity and Conservation, 24 (11), 28092830.

Mackenzie, C.A.; Chapman, C.A.; Sengupta, R. (2012). Spatial patterns of illegal resource extraction in Kibale National Park, Uganda. Environmental Conservation, 39 (01), 38-50.

Mancini, A.; Senko, J.; Borquez-Reyes, R.; Póo, J.G.; Seminoff, J.A.; Koch, V. (2011). To poach or not to poach an endangered species: elucidating the economic and social drivers behind illegal sea turtle hunting in Baja California Sur, Mexico. Human Ecology, 39 (6), 743-756.

Manfredo, M.J.; Teel, T.L.; Henry, K.L. (2009). Linking society and environment: A multilevel model of shifting wildlife value orientations in the western united states*. Social Science Quarterly, 90 (2), 407-427.

Marealle, W.N.; Fossøy, F.; Holmern, T.; Stokke, B.G.; Røskaft, E. (2010). Does illegal hunting skew Serengeti wildlife sex ratios? Wildlife Biology, 16 (4), 419-429.

Masanja, G.F. (2014). Human population growth and wildlife extinction in Ugalla ecosystem, western Tanzania. Journal of Sustainable Development Studies, 5 (2), 192.

Mascia, M.B.; Brosius, J.P.; Dobson, T.A.; Forbes, B.C.; Horowitz, L.; McKean, M.A.; Turner, N.J. (2003). Conservation and the social sciences. Conservation Biology, 17 (3), 649-650.

McMurray, C. A. (2008). Wildlife trafficking: US efforts to tackle a global crisis. Nat. Resources \& Env't, 23, 16.

Mrema P., E.; Barrat, S. (2016). The Rise of Environmental Crime - A Growing Threat To Natural Resources Peace, Development And Security. A UNEP INTERPOL Rapid Response Assessment. United Nations Environment Programme and RHIPTO Rapid ResponseNorwegian Center for Global Analyses, www.rhipto.org

Mgawe, P.; Borgerhoff Mulder, M.; Caro, T.; Martin, A.; Kiffner, C. (2012). Factors affecting bushmeat consumption in the Katavi-Rukwa ecosystem of Tanzania. Trop Conserv Sci, 5 (4), 446-462.

Milner-Gulland, E.J. (2012). Interactions between human behaviour and ecological systems. Philosophical Transactions of the Royal Society of London.Series B, Biological Sciences, 367 (1586), 270-278. 
Milner-Gulland, E.J.; Bennett, E.L. (2003). Wild meat: the bigger picture. Trends in Ecology \& Evolution, $18(7), 351-357$.

Moro, M.; Fischer, A.; Czajkowski, M.; Brennan, D.; Lowassa, A.; Naiman, L.C.; Hanley, N. (2013). An investigation using the choice experiment method into options for reducing illegal bushmeat hunting in western Serengeti. Conservation Letters, 6 (1), 37-45.

Muhumuza, M.; Balkwill, K. (2013). Factors affecting the success of conserving biodiversity in national parks: a review of case studies from Africa [online]. Hindawi Publishing Corporation. Available at: http://dx.doi.org/10.1155/2013/798101 [Accessed 01/12 2014].

Nachihangu, J.K.; Kiondo, K.; Lwelamira, K. (2018). Community Participation in Resident Hunting in South West Rungwa Game Reserve. Journal of Scientific Research \& Reports 18(5): 1-15.

Nasi, R.; Brown, D.; Wilkie, D.; Bennett, E.; Tutin, C.; Van Tol, G.; Christophersen, T. (2008). Conservation and use of wildlife-based resources: the bushmeat crisis. Secretariat of the Convention on Biological Diversity, Montreal. And Center for International Forestry Research (CIFOR), Bogor.Technical Series, 33, 1-50.

Nasi, R.; Taber, A.; Van Vliet, N. (2011). Empty forests, empty stomachs? Bushmeat and livelihoods in the Congo and Amazon Basins. International Forestry Review, 13(3), 355-368.

Naughton-Treves, L. (2002). Wild animals in the garden: Conserving wildlife in Amazonian agroecosystems. Annals of the Association of American Geographers, 92 (3), 488-506.

Nellemann, C.; Henriksen, R.; Raxter, P.; Ash, N.; Mrema, E. (2014). The environmental crime crisis: threats to sustainable development from illegal exploitation and trade in wildlife and forest resources.

Nielsen, M.R. (2006). Importance, cause and effect of bushmeat hunting in the Udzungwa Mountains, Tanzania: Implications for community based wildlife management. Biological Conservation, 128 (4), 509-516.

Nielsen, M.R.; Meilby, H. (2015). Hunting and trading bushmeat in the Kilombero Valley, Tanzania: motivations, cost-benefit ratios and meat prices. Environmental Conservation, 42 (01), 61-72.
Nigerian Conservation Foundation (2013). Biodiversity and Socio-economic Survey of Oba Hills Forest Reserve. Technical report submitted to the Government of the State of Osun. Pp30

Olaniyi, O.E.; Akinsorotan O.A.; Zakaria, M.; Martins, C.O.; Adebola, S.I.; Oyelowo, O.J. (2019). Taking the edge off host communities' dependence on protected areas in Nigeria. IOP Conference Series: Earth and Environmental Science (In press)

Ostrom, E. (2010). Beyond markets and states: polycentric governance of complex economic systems. Transnational Corporations Review, 2 (2): $1-12$.

Oyegbami, A.I.; Soewu, D.A.; Oyatogun, M.O.; Ijiwade, E.O. (2018). Utilization of Wild Animals Used for Bushmeat in South Western Nigeria: Implications for Wildlife Conservation. Proceedings of 6th NSCB Biodiversity Conference; Uniuyo 2018. pp155 - 159

Petrozzi, F.; Amori, G.; Franco, D.; Gaubert, P.; Pacini, N.; Eniang, E.A.; Akani, G.C.; Politano, E.; Luiselli, L. (2018). Ecology of the bushmeat trade in West and Central Africa. Tropical Ecology 57(3): 547-559, 2016

Rentsch, D.; Damon, A. (2013). Prices, poaching, and protein alternatives: An analysis of bushmeat consumption around Serengeti National Park, Tanzania. Ecological Economics 91: 1-9

Ripple, W.J.; Abernethy, K.; Betts, M.J.; Chapron, G.; Dirzo, R.; Galetti, M.; Levi, T.; Lindsey, P.A.; Macdonald, D.W.; Machovina, B.; Newsome, T.M.; Peres, C.A.; Wallach, A.D; Wolf, C.W.; Young, H. (2016). Bushmeat hunting and extinction risk to the world's mammals $R$. Soc. open sci. $\quad 3$ : 160498. http://dx.doi.org/10.1098/rsos.160498

Robinson, J.G.; Bennett, E.L. (2002). Will alleviating poverty solve the bushmeat crisis? Oryx, 36 (04), 332-332.

Robinson, J.G.; Bennett, E.L. (2004). Having your wildlife and eating it too: an analysis of hunting sustainability across tropical ecosystems. Animal Conservation, 7 (4), 397-408.

Roe, D.; Elliott, J. (2006). Pro-poor conservation: the elusive win-win for conservation and poverty reduction. Policy Matters, 14 (03), 2006.

Roe, D.; Booker, F.; Day, M.; Zhou, W.; AlleboneWebb, S.; Hill, N.A.; Kumpel, N.; Petrokofsky, G.; Redford, K.; Russell, D. (2015). Are 
alternative livelihood projects effective at reducing local threats to specified elements of biodiversity and/or improving or maintaining the conservation status of those elements? Environmental Evidence, 4 (1), 1.

Roe, D.; Day, M.; Booker, F.; Zhou, W.; AlleboneWebb, S.; Kümpel, N.; Hill, N.A.; Wright, J.; Rust, N.; Sunderland, T.C. (2014). Are alternative livelihood projects effective at reducing local threats to specified elements of biodiversity and/or improving or maintaining the conservation status of those elements?: a systematic review protocol. Environmental Evidence, 3 (1), 1.

Schenck, M.; Effa, E.N.; Starkey, M.; Wilkie, D.; Abernethy, K.; Telfer, P.; Godoy, R.; Treves, A. (2006). Why people eat bushmeat: Results from two-choice, taste tests in Gabon, Central Africa. Human Ecology, 34 (3), 433-445.

Schulte-HerbruEggen, B.; Cowlishaw, G.; Homewood, K.; Rowcliffe, J.M. (2017). Rural protein insufficiency in a wildlife-depleted West African farm-forest landscape. PLoS ONE 12(12): e0188109.

Singh, S.; Sharma, C. (2009). Tropical ecology: an overview. Tropical Ecology, 50 (1), 7.

St John, F.A.; Keane, A.M.; Edwards-Jones, G.; Jones, L.; Yarnell, R.W.; Jones, J.P. (2012). Identifying indicators of illegal behaviour: carnivore killing in human-managed landscapes. Proceedings. Biological Sciences / the Royal Society, 279 (1729), 804-812.

St John, F.A.; Keane, A.M.; Jones, J.P.; MilnerGulland, E. (2014). FORUM: Robust study design is as important on the social as it is on the ecological side of applied ecological research. Journal of Applied Ecology, 51 (6), 1479-1485.

Tomićević, J.; Shannon, M.A.; Milovanović, M. (2010). Socio-economic impacts on the attitudes towards conservation of natural resources: case study from Serbia. Forest Policy and Economics, $12(3), 157-162$.
Treves, A. (2009). Hunting for large carnivore conservation. Journal of Applied Ecology, 46 (6), 1350-1356.

UNEP (2016). Global Gender and Environment Outlook The Critical Issues. United Nations Environment Programme, Nairobi, Kenya. Pp107.

Usman, B.; Adefalu, L. (2010). Nigerian forestry, wildlife and protected areas: Status report. Biodiversity, 11 (3-4), 54-62.

Vega, M.G.; Carpinetti, B.; Duarte, J.; Fa, J.E. (2013). Contrasts in livelihoods and protein intake between commercial and subsistence bushmeat hunters in two villages on Bioko Island, Equatorial Guinea. Conservation Biology, 27 (3), 576-587.

Walsh, P.D.; Abernethy, K.A.; Bermejo, M.; Beyers, R.; De Wachter, P.; Akou, M.E.; Huijbregts, B.; Mambounga, D.I.; Toham, A.K.; Kilbourn, A.M. (2003). Catastrophic ape decline in western equatorial Africa. Nature, 422 (6932), 611-614.

Wilfred, P.; MacColl, A.D. (2010). Income sources and their relation to wildlife poaching in Ugalla ecosystem, Western Tanzania. African Journal of Environmental Science and Technology, 4 (12), 886-896.

Wilkie, D.S.; Starkey, M.; Abernethy, K.; Effa, E.N.; Telfer, P.; Godoy, R. (2005). Role of prices and wealth in consumer demand for bushmeat in Gabon, Central Africa. Conservation Biology, 19 (1), 268-274.

Wittemyer, G.; Northrup, J. M.; Blanc, J.; DouglasHamilton, I.; Omondi, P.; Burnham, K. P. (2014). Illegal killing for ivory drives global decline in African elephants. Proceedings of the National Academy of Sciences, 111(36), 13117-13121. 